\title{
Small Farm Food Safety, Fresh Produce: Part 5 - Your Farm Food Safety Plan 1
}

Brian Lapinski, Amy Simonne and M.E. Swisher ${ }^{2}$

Time Required: 15 minutes

\section{Materials for Trainer}

- Chalkboard or flipboard with markers to record participant ideas

\section{Advance Preparation for Trainer}

- Review "Guide to Minimize Microbial Food Safety Hazards for Fresh Fruits and Vegetables," U.S. Dept. of Health and Human Services, Food and Drug Administration, Center for Food Safety and Applied Nutrition, October 1998.

- Preview materials in this section to prepare yourself to facilitate the learning experience.

\section{Materials for participants}

- Passing along Best Practices

\section{Objectives}

- Application objective
Participants will be prepared to train workers and associates on proper food safety.

\section{- Learning objective}

Participants will understand how to enhance food safety training.

\section{Procedure}

- Print and distribute one copy of "Passing along Best Practices" to each participant.

- Break this exercise into two parts.

- First, have participants list the five most important food safety practices that each participant needs to teach new workers on his or her farm in order to avoid potential hazards of microbial contamination. Stress that these practices should be specific to the participant's farm--not general.

- Ask each participant to share at least one of the practices he/she listed with the group.

- As participants share their ideas, write them down on a flip chart.

1. This document is FCS8846, one of a series of the Family Youth and Community Sciences Department, Florida Cooperative Extension Service, Institute of Food and Agricultural Sciences, University of Florida. Original publication date October 5, 2007. Visit the EDIS Web Site at http://edis.ifas.ufl.edu.

2. Brian Lapinski, graduate student, Amy Simonne, associate professor and M.E. Swisher, associate professor, Department of Family, Youth and Community Sciences, Institute of Food and Agricultural Sciences, University of Florida, Gainesville, 32611.

The Institute of Food and Agricultural Sciences (IFAS) is an Equal Opportunity Institution authorized to provide research, educational information and other services only to individuals and institutions that function with non-discrimination with respect to race, creed, color, religion, age, disability, sex, sexual orientation, marital status, national origin, political opinions or affiliations. U.S. Department of Agriculture, Cooperative Extension Service, University of Florida, IFAS, Florida A. \& M. University Cooperative Extension Program, and Boards of County Commissioners Cooperating. Larry Arrington, Dean 
- If some of the key practices listed below are not mentioned, raise them yourself.

- Then have each participant list the techniques or ideas that he/she should use to make sure that people that are working on his/her farm are actually following the best farm practices mentioned in the first list.

- Ask each participant to share at least one of the practices he/she listed with the group.

- As participants share their ideas, write them down on a flip chart.

- If some of the key practices listed below are not mentioned, raise them yourself.

\section{Key practices}

- Wash your hands!

- Take a bathroom break when necessary (but not in the field).

- Wear gloves when touching produce.

- Triple-wash leafy vegetables.

- Be aware of microbial sources, such as manure piles, and avoid cross-contamination.

- Keep animals (including pets) away from vegetables--especially after the produce has been washed.

\section{Techniques for making sure best practices are used}

- Post signs (but not too many) in strategic locations.

- Thorough training session upon first arrival.

- Review trainings within the year.

- A manual of procedures to consult placed in a convenient location.

\section{Passing along Best Practices}

Having a sound plan to deal with issues of food safety on your farm is very important. If you do not clearly pass on those plans to those you work with, your farm can be at risk.

Imagine you have someone who is new or nearly new to your farm (a new employee, a family member, a volunteer, a friend, a neighbor, a relative). List the five most important food safety practices you need to teach this person to avoid potential hazards of microbial contamination on YOUR farm.

1.

2.

3.

4.

5.

As anyone who has managed people knows, telling someone something and having them do it are two different things! What techniques or ideas should you use to make sure that people that are working on YOUR farm are actually following your best farm practices? List five techniques below (like putting up signs).

1.

2.

3.

4.

5.

To obtain copies of the DVD that accompanies this publication, please contact the IFAS Extension Bookstore at 1-800-226-1764 or order online at www.ifasbooks.com. 